\title{
Forms AND PROJEctions OF WORD MAGIC AS A CULTURAL VALUE IN FOLK PROSE
}

\section{L'UBOMÍR GÁBOR}

JAN STANISLAV INSTITUTE OF SLAVISTICS, SLOVAK ACADEMY OF SCIENCES lubomir.gabor@gmail.com

The aim of this paper is to illustrate the forms and meaning of word magic in selected genres of oral folklore, with an emphasis on magic fairy tales of Slovak origin. The role of word magic in folklore narratives will be interpreted from an anthropological point of view as a significant phenomenon of the cultural memory of human societies referring to the theorems of the archaeology of literary communication.

Keywords: word magic, magic fairy tales, folklore, cultural axiom

\section{REFERENCES}

Assmann A., Assmann J. 1997: Assmann, A., J. Assmann. Zur Einführung. - In: Assman, A. et al. Schleier und Schwelle. Archäologie der literarischen Kommunkation V/1. Geheimnis und Öffentlichkeit. Mníchov, Wilhelm Fink Verlag, s. 7-16.

Assmann, A., Assmann, J. 1999: Assmann, A., J. Assmann. Archeologie literární komunikace. - In: Pechlivanos, M. (ed.). Úvod do literární vědy. Praha, Herrmann \& synové, $454 \mathrm{~s}$.

Assmann 2001: Assmann, J. Kultura a pamět'. Praha, Prostor, $320 \mathrm{~s}$.

Brandt 1997: Brandt $R$. ... his stupris incumbere non pertimescit publice. Heimlichekit zum Schutz sozialer Konformität im Mittelalter. - In: Assmann, A. et al. Schleier und Schwelle. Archäologie der literarischen Kommunkation V/1. Geheimnis und Öffentlichkeit. Mníchov, Wilhelm Fink Verlag, s. 71-88.

Burkert 2003: Burkert, W. Antike Mysterien. Mníchov, Beck Verlag, 156 s.

Filová, Gašparíková 2001: Filová, B., V. Gašparíková (eds.). Slovenské l'udové rozprávky II. Bratislava, Veda, $1076 \mathrm{~s}$.

Filová, Gašparíková 2002: Filová, B., V. Gašparíková (eds.). Slovenské l'udové rozprávky I. Bratislava, Veda, $768 \mathrm{~s}$.

Gašparíková 2001: Gašparíková V. Porovnávacie komentáre k jednotlivým rozprávkovým textom. - In: Filová, B., V. Gašparíková (eds.). Slovenské ludové rozprávky II. Bratislava, Veda, s. 906-1053.

Gašparíková 2002: Gašparíková, V. Porovnávacie komentáre k jednotlivým rozprávkovým textom. - In: Filová, B., V. Gašparíková (eds.). Slovenské l’udové rozprávky I. Bratislava, Veda, s. 620-748.

Gábor 2015: Gábor, L. Baláž z Dobšinského Prostonárodných slovenských povestí. Pohansko-krest’anský synkretizmus ako možná výkladová schéma l'udovej 
rozprávky. - In: ŽEŇUCHOVÁ, K. (ed.). Ludová próza na Slovensku v kontexte dejín slavistiky. Bratislava, Slavistický ústav Jána Stanislava SAV, s. $113-131$.

Gábor 2015: Gábor, L'. Formy, prejavy a mytologické aspekty hraníc v l'udovej rozprávke. In: Slavica Slovaca. Bratislava, SÚJS SAV, 2015, roč. 50, č. 2, s. $116-131$.

Gábor 2016: Gábor, L'. Iniciácia vo folklórnych rozprávkach - rituálna fikcia a fiktívny rituál. - In: Gábor, L., Rožai, G.: Tváre (ne)reality v literatúre. Banská Bystrica, FF UMB, s. 182-195.

Gábor 2017: Gábor, L. Ludová próza západných Slovanov v komparatistickej perspektíve. Sondy do literárnej predhistórie. Banská Bystrica, FF UMB, $154 \mathrm{~s}$.

Hahn 1997: Hahn, A. Soziologische Aspekte von Geheimnissen und ihren Äquivalenten. - In: Assmann, A. et al. Schleier und Schwelle. Archäologie der literarischen Kommunkation V/1. Geheimnis und Öffentlichkeit. Mníchov, Wilhelm Fink Verlag, s. 23-40.

Haupt 1991: Haupt, K. Sagenbuch der Lausitz. Bautzen, Domowina-Verlag, 1991. $234 \mathrm{~s}$.

Králik 2015: Králik, L. Stručný etymologický slovník slovenčiny. Bratislava, Veda, $704 \mathrm{~s}$.

Lévi-Strauss 2000: Lévi-Strauss, C. Štrukturálna antropológia. Bratislava, Kalligram, $416 \mathrm{~s}$.

Moric 1975: Moric, R. O Blažejovi, čo sa nebál. Bratislava, Mladé letá, $80 \mathrm{~s}$.

Nádaská 2014: Nádaská, K. Čary a veštby. Bratislava, Fortuna Libri, 200 s.

Polívka 1930: Polívka, J. Súpis slovenských rozprávok IV. Martin, Matica slovenská, $560 \mathrm{~s}$.

Polívka 1931: Polivka, J. Súpis slovenských rozprávok V. Martin, Matica slovenská, $536 \mathrm{~s}$.

Propp 1971: Propp, V. Morfológia rozprávky. Bratislava, Tatran, $192 \mathrm{~s}$.

Uther 2004: Uther, H.-J. The Types of International Folktales. A Classification and Bibliography Based on the System of Antti Aarne and Stith Thompson. 1. zv. Helsinki, STASF, $619 \mathrm{~s}$.

Záturecký 1975: Záturecký, Adolf P. Slovenské príslovia, porekadlá a úslovia. Bratislava, Tatran, $761 \mathrm{~s}$.

$\triangle$ L'ubomír Gábor, PhD

Slavistický ústav Jána Stanislava SAV

Dúbravska cesta 9

84104 Bratislava, Slovensko 